\title{
Broad Protein Spectrum in Stored Pollen of Three Stingless Bees from the Chaco Dry Forest in South America (Hymenoptera, Apidae, Meliponini) and Its Ecological Implications
}

\author{
Favio Gerardo Vossler \\ Laboratorio de Actuopalinología, CICyTTP-CONICET/FCyT-UADER, Dr. Materi y España, Diamante, \\ E3105BWA Entre Ríos, Argentina
}

Correspondence should be addressed to Favio Gerardo Vossler; favossler@yahoo.com.ar

Received 26 September 2015; Accepted 2 November 2015

Academic Editor: David Roubik

Copyright (C) 2015 Favio Gerardo Vossler. This is an open access article distributed under the Creative Commons Attribution License, which permits unrestricted use, distribution, and reproduction in any medium, provided the original work is properly cited.

Protein content of pollen stored by three meliponine species was variable from $9.78 \%$ (less than half the value considered as optimal to brood development in Apis mellifera) in type Capparis tweediana-C. speciosa to more than $26 \%$ in type Maytenus vitis-idaea and some Prosopis samples. This pollen of low protein value was occasionally foraged (only six out of 75 masses analyzed of G. argentina, but none in 86 masses of T. fiebrigi or in ten of M. orbignyi). However, it is likely that amino acid deficiencies of certain pollens are compensated by randomly foraging on a broad spectrum of pollen plants. The large amounts of pollen stored in their nests might also be important in compensating these deficiencies. The only sample studied for M. orbignyi showed a protein value greater than the one required for A. mellifera and was dominated by types Acacia praecox and Prosopis. As this species also prefers Solanum and other protein-rich pollen, more samples would need to be analyzed to establish whether protein requirements are high for this Melipona species. Pollen showing the highest protein content (>26\%) belonged to highly nectariferous plants well represented in meliponine and Apis honey such as Prosopis, Maytenus, and Ziziphus.

\section{Introduction}

The stingless bees (Apidae: Meliponini) are eusocial and they build perennial nests with hundreds to thousands of individuals and high reproductive rate $[1,2]$. To maintain their colonies, high amounts of pollen and nectar are foraged from flowers, the former stored as pollen masses and the latter as honey in pots made of cerumen. Pollen pots are located mainly surrounding the brood area where young individuals are growing [3]. Pollen stored in nests is chemically and biochemically different from fresh pollen from anthers or pollen loads from the same plant species due to regurgitated liquids incorporated during packing [47]. Mutualistic bacteria were found in stored pollen and honey of nine Apis species, Melipona fasciata panamica Cockerell, Melipona beecheii Bennett, Meliponula bocandei (Spinola), and Trigona producing enzymes that may facilitate storage and/or digestion by bees and secrete antibiotics and fatty acids to inhibit microorganisms that cause spoilage of stored food $[8,9]$. During periods of general food shortage, Melipona species show conservative trends eating young larvae and provisions and drastically decreasing brood production [10]. Although exceptional protein resources such as soybean bran in Geotrigona mombuca (Smith) (sub G. inusitata in [11]) and flesh of dead animals in many Trigona, Partamona, Oxytrigona, Cephalotrigona, and others [12] can be facultatively gathered, pollen is the main protein source in bees. Obligate necrophagy (dead animal flesh is the only protein source) occurs only in Trigona crassipes (Fabricius), T. hypogea Silvestri, and T. necrophaga Camargo \& Roubik [11, 13-15]. For Apis mellifera, the higher the crude protein percentage the lesser amount of pollen required to sustain production [16]. Ample protein content promotes a high birth rate and long-lived bees, $20 \%$ being the minimum protein 
amount required by colonies for optimum production [17]. A well-nourished bee colony is a guarantee for good level of honey flow and breeding [16].

It is important to know pollen protein intake of meliponine bees for appropriate colony rearing (meliponiculture), as it would be useful to determine supplemental feeding needed in periods of flowering shortage. Stingless bees are important for pollination of wild and crop plants [18] and for bee-products production (honey, pollen, resin, and cerumen) [19]. The aims of the present study were to determine protein content of pollen stored in nests of three meliponine bee species (Tetragonisca fiebrigi (Schwarz), Melipona orbignyi (Guérin), and Geotrigona argentina Camargo \& Moure) from the South American Chaco dry forest. These are three out of the seven species recorded for this area [20,21] being important mainly for rural population for their honey, pollen masses, larvae, and cerumen [22].

\section{Materials and Methods}

2.1. Sampling and Study Area. Pollen mass from cerumen pots was obtained from nests of Tetragonisca fiebrigi (Schwarz), Melipona orbignyi (Guérin), and Geotrigona argentina Camargo \& Moure from xeric forests in the Chaco region of Northern Argentina (Figure 1). Samples for protein analysis were taken from nest 7 of $T$. fiebrigi, nest 11 of $M$. orbignyi, and nests 2 and 4 of $G$. argentina from $\mathrm{El}$ Sauzalito $\left(24^{\circ} 24^{\prime} \mathrm{S}, 61^{\circ} 40^{\prime} \mathrm{W}\right)$, from nest 1 of $G$. argentina from El Espinillo (25 $\left.24^{\prime} \mathrm{S}, 60^{\circ} 27 \mathrm{~W}\right)$, from nest 5 of T. fiebrigi from Miraflores $\left(25^{\circ} 29^{\prime} \mathrm{S}, 61^{\circ} 01^{\prime} \mathrm{W}\right)$, and from nest 12 of $T$. fiebrigi from Villa Río Bermejito $\left(25^{\circ} 37^{\prime} \mathrm{S}\right.$, $\left.60^{\circ} 15^{\prime} \mathrm{W}\right)$. This Chaco dry forest is characterized by the dominance of "palo santo" (Bulnesia sarmientoi Lorentz ex Griseb., Zygophyllaceae) and "quebracho blanco" trees (Aspidosperma quebracho-blanco Schltdl., Apocynaceae), or by "quebracho colorado santiagueño" (Schinopsis lorentzii Engl., Anacardiaceae), "quebracho colorado chaqueño" (Schinopsis balansae Engl.), and "quebracho blanco" [23, 24]. Other woody elements well represented in this xerophilous flora are "mistol" (Ziziphus mistol Griseb., Rhamnaceae), "molle" or "guaraniná” (Sideroxylon obtusifolium (Roem. \& Schult.) T. D. Penn., Sapotaceae), several species of Prosopis ("algarrobo blanco," "algarrobo negro," "vinal," "vinalillo," “carandá," and "guachín”) (Fabaceae, Mimosoideae), "guayacán” (Caesalpinia paraguariensis (D. Parodi) Burkart, Fabaceae, Caesalpinioideae), "tipa colorada" or "palo coca" (Pterogyne nitens Tul., Fabaceae, Caesalpinioideae), "palo cruz" (Tabebuia nodosa (Griseb.) Griseb., Bignoniaceae), "quebrachillo" (Aspidosperma triternatum Rojas Acosta, Apocynaceae), "palo borracho" or “yuchán” (Ceiba chodatii (Hassl.) Ravenna, Bombacaceae), "palma de monte" (Trithrinax schizophylla Drude, Arecaceae), "meloncillo" (Castela coccinea Griseb., Simaroubaceae), "palo tinta" (Achatocarpus praecox Griseb., Achatocarpaceae), "tala” (Celtis spp., Celtidaceae), "duraznillo" (Salta triflora (Griseb.) Adr. Sánchez, Polygonaceae), "pata” (Ximenia americana L., Olacaceae), "molle" (Schinus fasciculatus (Griseb.) I. M. Johnst. var. arenicola (Hauman) F. A. Barkley, Anacardiaceae), "chañar"
(Geoffroea decorticans (Gillies ex Hook. \& Arn.) Burkart, Fabaceae, Papilionoideae), "sal de indio" or "sal de monte" (Maytenus vitis-idaea Griseb., Celastraceae), "paloma yuyo" (Moya spinosa Griseb., Celastraceae), "teatín” (Mimosa detinens Benth., Fabaceae, Mimosoideae), "cardón” (Stetsonia coryne (Salm-Dyck) Britton \& Rose, Cactaceae), "ucle" (Cereus forbesii Otto ex C. F. Först., Cactaceae), two species of Bougainvillaea ("rama overa") (Nyctaginaceae), several species of Acacia ("tusca," "garabato," and "churqui") (Fabaceae, Mimosoideae), Capparis ("atamisqui," "sacha membrillo," "sacha sandia," "sacha poroto," and "bola verde"), and "cardo" or "chaguar" (several Bromeliaceae genera), among others.

2.2. Pollen Analysis of Pollen Masses and Plant and Bee References. Pollen masses were dissolved in distilled water at $80-90^{\circ} \mathrm{C}$ and stirred with a magnetic stirrer for $10-15 \mathrm{~min}$. A representative mixture of $5-10 \mathrm{~mL}$ was obtained and centrifuged at $472 \times \mathrm{g}$ for $5 \mathrm{~min}$. Processing included acetolysis [25]. Under a Nikon Eclipse E200 light microscope, a total of 300-500 pollen grains per slide were counted. Pollen grain identification was carried out comparing nest pollen slides with those present in the reference pollen collection. The reference slides consist of a total of 190 plant species and are deposited in PAL-CICYTTP pollen collection of Diamante, Entre Ríos, Argentina. It was made from flower buds of plant species collected in various localities from Chaco Province of Argentina. These plant specimens were pressed, dried, and identified by the author and deposited in the Herbarium of the Museo de La Plata (LP), the Herbarium of Museo Argentino de Ciencias Naturales "Bernardino Rivadavia" (BA), Buenos Aires, and the Herbarium Lorentz (DTE) of Diamante, Entre Ríos, Argentina. Plant nomenclature follows [26]. Bee specimens were collected from nests, identified by Arturo Roig-Alsina, and deposited in the Entomology Collection of the Museo Argentino de Ciencias Naturales "Bernardino Rivadavia", Buenos Aires, Argentina.

2.3. Determination of Protein Content. To quantify protein of pollen resources foraged by bees, certain pollen masses were selected according to their pollen type composition. Six pollen mass samples were taken from nests 5, 7, and 12 of Tetragonisca fiebrigi, one from nest 11 of Melipona orbignyi, and eight from nests 1, 2, and 4 of Geotrigona argentina (Table 1). For nitrogen content determination, $50 \mathrm{mg}$ of pollen [27] was analyzed by the micro-Kjeldahl method [28] and crude protein was estimated using the factor 6.25 [29]. Pollen nitrogen content was analyzed in LANAIS N15 (National Laboratory of Research and Services UNS-CONICET), Departamento de Agronomía, Universidad Nacional del Sur, Bahía Blanca, Argentina.

\section{Results}

3.1. Protein Content of Pollen Stored in Meliponine Nests. Nitrogen values from pollen grains stored in pollen pots of the three meliponine species studied varied from 1.56 to $4.86 \%$, which is equivalent to 9.78 to $30.41 \%$ of crude 


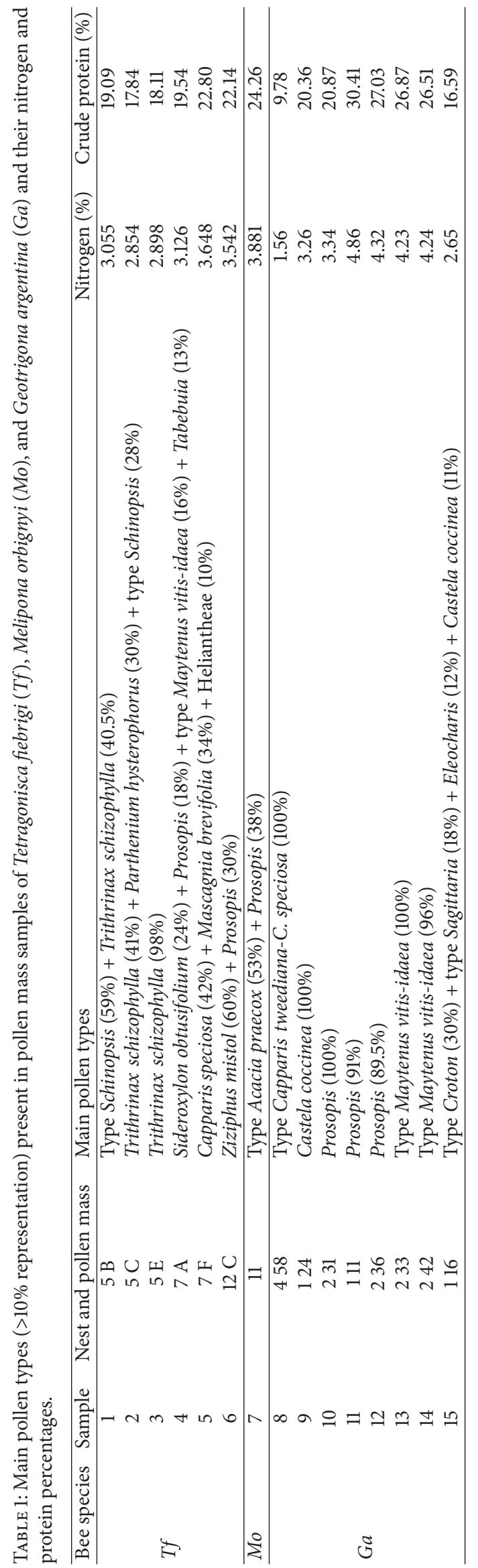




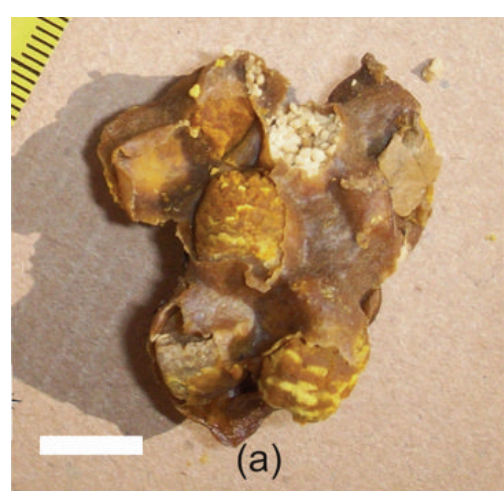

(a)

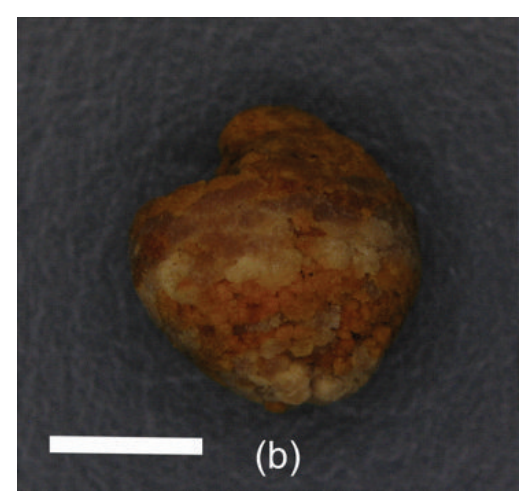

(b)

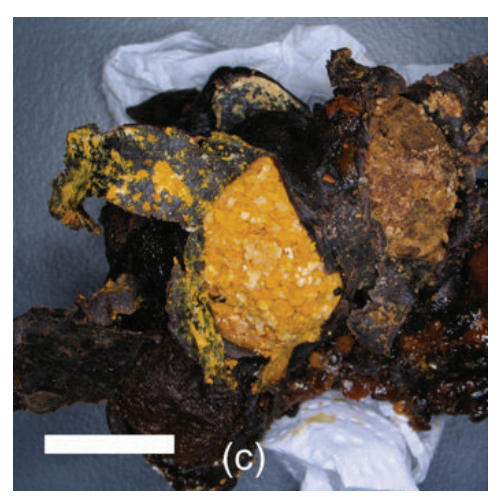

(c)

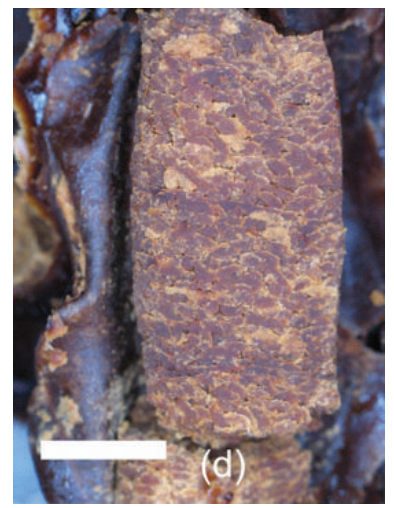

(d)

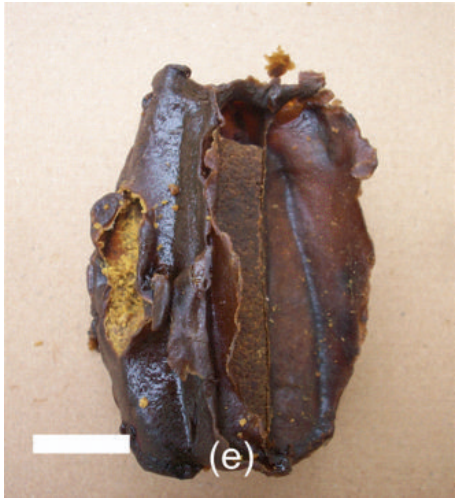

(e)

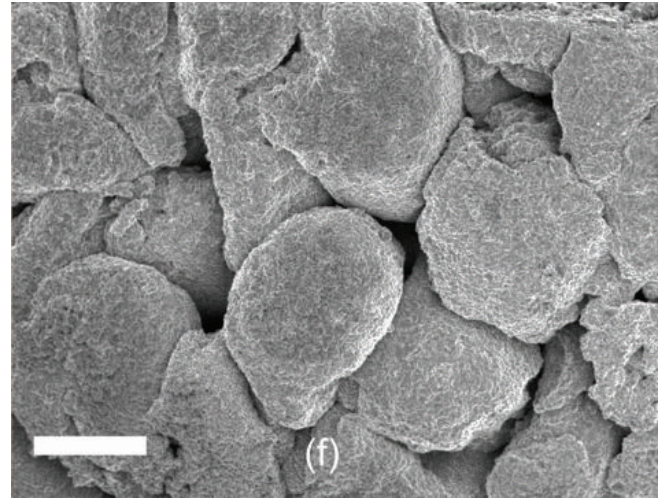

(f)

FIGURE 1: General aspect of pollen masses of Tetragonisca fiebrigi (a, b), Melipona orbignyi (c), and Geotrigona argentina (d, e). Individual loads from pollen masses can be seen in scanning microscope (f). Bars: (a) $10 \mathrm{~mm}$; (b) $5 \mathrm{~mm}$; (c) $20 \mathrm{~mm}$; (d) $10 \mathrm{~mm}$; (e) $20 \mathrm{~mm}$; (f) $1 \mathrm{~mm}$.

protein (Table 1). Higher protein values ( $>20 \%$ ) were found in samples having the following composition: Prosopis (samples 10,11 , and 12 of $G$. argentina), type Maytenus vitis-idaea (samples 13 and 14 of G. argentina), type Acacia praecox + Prosopis (sample 7 of M. orbignyi), Capparis speciosa + Mascagnia brevifolia + Heliantheae (sample 5 of T. fiebrigi), Ziziphus mistol + Prosopis (sample 6 of T. fiebrigi), and Castela coccinea (sample 9 of G. argentina) (Table 1). The remaining samples showed less than $20 \%$ of crude protein; the lowest value $(<10 \%)$ found was for type Capparis tweedianaC. speciosa (sample 8 of G. argentina).

Protein values found in samples composed mainly of herbs, climbers, or shrubs differed greatly among them (9.78$22.8 \%$ ) and were slightly lower than those dominated by trees (17.84-30.41\%). A broader range of protein values was found for $G$. argentina $(9.78-30.41 \%)$ than for T. fiebrigi (17.84$22.80 \%)$.

\section{Discussion}

If protein content of pollen grains was constant for all individuals of each plant species, samples composed only or mostly of one pollen type (96-100\%) (6 samples in the present study) would indicate their real protein value and it would be useful for comparing samples composed of many pollen types.
Nutritive value of pollen grains is affected by air temperature, soil moisture, $\mathrm{pH}$, and soil fertility, among other factors [30] but a range of values is expected for a particular species under the same conditions [16]. The two samples dominated by type Maytenus vitis-idaea had similarly high protein values (26.51 and $26.87 \%$ ), followed by Castela coccinea that ranked near $20 \%$, the minimum limit value considered as optimal to brood development in Apis mellifera L. [17], and the palm tree Trithrinax schizophylla with slightly less than $20 \%$. The lowest protein value was from type Capparis tweediana-C. speciosa with less than half the optimal value. Inconsistency among pollen type composition and protein value was found for the three samples dominated by Prosopis as pure Prosopis pollen showed lower protein values than those composed of 91 and $89.5 \%$ Prosopis and approximately 10\% of other types (9.2\% Ziziphus mistol in sample 11 and 9.5\% Capparis salicifolia $+1 \%$ Ruprechtia triflora in sample 12 ). It appears that these accompanying pollen types were providers of important amounts of proteins. Nevertheless, the differences of protein content detected in these three samples could be due to the fact that different species of Prosopis (similar at light microscope) were present in their composition, as many Prosopis species are highly abundant in arboreal and shrubby strata of the Chaco forest and meliponine bees forage on all of them. On the other hand, soil fertility can influence nitrogen 
and consequent protein composition of plant individuals [30]. The dry Chaco is a xerophytic forest that alternates with water bodies such as ancient rivers and their related riparian vegetation [31]. Nests of meliponine species here studied were sampled from these environments, and bees could forage on flowers from both dry forest patches and water bodies composed of plants growing under different nitrogen level. Moreover, livestock grazing in the forest is a very common practice in the area studied and it is responsible for increasing soil nitrogen levels through excreta. Local differences of nitrogen levels in soil might be the cause for differences in protein amounts found in pollen masses dominated by a same pollen type (the case of Prosopis). Fertilizer incidence was discarded, as agricultural crops were absent in the sampled area.

Stored pollen in Apis mellifera colonies (pollen bread) is probably fermented by lactic acid bacteria of the genera Lactobacillus and Bifidobacterium from the honey stomach added to the pollen via regurgitated nectar $[6,7]$. Over and above their significance in pollen bread production and storage, these lactic acid bacteria are important against pathogens and production and storage of honey [6,9]. These microbial symbionts are also present in its ecologically similar and closely related group: the stingless bees (Meliponini) [9, 32]. Proteins, mainly enzymes, are secreted by this beneficial microbiota during stress [33], which could increase the protein content of stored pollen. Versatile digestive physiologies characterize broad polylectic bees [34], as pollen of diverse protein spectrum seems to be similarly foraged by these highly social species. Similar to other studies on bee foraged pollen $[35,36]$, protein content of pollen types was variable. It is likely that amino acids deficiencies of certain pollen are compensated by randomly foraging on a broad spectrum of pollen plants. This is in agreement with the argument stated by [37] that nutritive value of pollen for bees is not directly correlated with protein quantity since a qualitative factor is of greater importance. For instance, [38] detected low protein levels in hand-collected pollen from desert plants (from 7 to $15.6 \%$ ), but they highlighted that their amino acid patterns were in agreement with the requirements for honey bees. An interesting topic to be tested by experimental studies is on the capability of meliponine brood to develop by eating pollen having the half of the optimal protein level for Apis mellifera. However, palynological surveys on meliponine bees from the Chaco region showed that scarce number of pollen masses are composed of pure or nearly pure pollen from Capparis tweediana or C. speciosa, having only $9.78 \%$ of protein (only six out of 75 masses analyzed of G. argentina, but none in 86 masses of T. fiebrigi or in ten of M. orbignyi) [39, FGV unpublished data]. Pollen with low protein levels would expose bees to more severe amino acids deficiencies. However, bees can be well developed when feeding on high amounts of these pollens, but a colony would be threatened when there is a low amount of pollen stores or shortage of flowerings [16]. Meliponine bees store great amounts of pollen (353 $\mathrm{g}$ in 20 pollen pots of diverse filling in one nest of G. argentina) [39] (Figure 1).

An attempt was made to determine the differences in protein content due to life-form of plants foraged and season when sampling was carried out and among bee species but further studies are necessary. However, most protein-rich pollen species were woody, in accordance with findings for other semiarid areas of Argentina [35] but findings by [36] did not show this pattern. It is widely known that Solanum species are protein-rich pollen resources, ranging from $34.1 \%$ for S. tabanoense Correll to $54.9 \%$ for S. lycopersicum L. [40]. Solanum was highly foraged by Melipona orbignyi [FGV unpublished data]. The only sample studied for $M$. orbignyi showed a protein value greater than the one required for $A$. mellifera and was dominated by types Acacia praecox and Prosopis followed by four types of less than $4 \%$ representation. As this species also prefers Solanum and other proteinrich pollen from poricidal anthers whose grains are easily gathered by vibratile buzzing, more samples would need to be analyzed to establish whether protein requirements are high for this Melipona species. The genus Solanum is well represented in the dry Chaco (more than 10 species), mainly in open areas of nitrogen-rich soils and water bodies.

It is surprising that pollen showing the highest protein content ( $>26 \%$ ) belonged to highly nectariferous plants well represented in meliponine and Apis honey in this region such as Prosopis, Maytenus, and Ziziphus [39, 41-45]. Studies on protein content of pollen loads and pollen analysis of honey carried out in other semiarid areas also show this tendency, as seen in Table III of [35] and Table II of [46] for Condalia, Brassicaceae and Prosopis, in Table III of [36], and in Table II of [47] for Adesmia, Rosaceae, Trifolium, Melilotus, Schinus, and Brassicaceae. Furthermore, pollen from the nectariferous Larrea and Prosopis showed the richest protein value in a study carried out in a North American desert [38]. This pattern of high protein value in pollen of highly nectariferous plants foraged by honey-producing bees is here hypothesized and should be further studied.

\section{Conflict of Interests}

The author declares that there is no conflict of interests regarding the publication of this paper.

\section{Acknowledgments}

The author thanks César Albornoz, Inocencio Medina, Isabel Brait, Rogelio Burgardt, Mercedes Koler, Ricardo "Nene" Vossler, and Juan Hiperdinger for their warm hospitality and help during the field studies in El Sauzalito, J. J. Castelli, El Espinillo, and Villa Río Bermejito and Nora Brea for providing suggestions and comments on the paper. The author is especially grateful to Arturo Roig-Alsina for identifying the bees. This study was supported by CONICET (Consejo Nacional de Investigaciones Científicas y Técnicas).

\section{References}

[1] D. W. Roubik, Ecology and Natural History of Tropical Bees, Cambridge University Press, New York, NY, USA, 1989.

[2] M. Ramalho, M. D. Silva, and C. A. L. Carvalho, "Dinâmica de uso de fontes de pólen por Melipona scutellaris Latreille (Hymenoptera: Apidae): uma análise comparativa com Apis 
mellifera L. (Hymenoptera: Apidae), no Domínio Tropical Atlântico," Neotropical Entomology, vol. 36, no. 1, pp. 38-45, 2007.

[3] D. W. Roubik, "Stingless bee nesting biology," Apidologie, vol. 37, no. 2, pp. 124-143, 2006.

[4] D. B. Casteel, "The behaviour of the honeybee in pollen collecting," Bulletin of the United States Department of Agriculture, Bureau of Entomology, vol. 121, pp. 1-36, 1912.

[5] M. H. Haydak, "Pollen substitutes," in Proceedings of the 10th International Congress of Entomology, vol. 4, pp. 1053-1055, Montreal, Canada, August 1958.

[6] T. C. Olofsson and A. Vásquez, "Detection and identification of a novel lactic acid bacterial flora within the honey stomach of the honeybee Apis mellifera," Current Microbiology, vol. 57, no. 4, pp. 356-363, 2008.

[7] A. Vásquez and T. C. Olofsson, "The lactic acid bacteria involved in the production of bee pollen and bee bread," Journal of Apicultural Research, vol. 48, no. 3, pp. 189-195, 2009.

[8] M. Gilliam, D. W. Roubik, and B. J. Lorenz, "Microorganisms associated with pollen, honey, and brood provisions in the nest of a stingless bee, Melipona fasciata," Apidologie, vol. 21, no. 2, pp. 89-97, 1990.

[9] A. Vásquez, E. Forsgren, I. Fries et al., "Symbionts as major modulators of insect health: lactic acid bacteria and honeybees," PLoS ONE, vol. 7, no. 3, Article ID e33188, 2012.

[10] D. W. Roubik, "Seasonality in colony food storage, brood production and adult survivorship: studies of Melipona in tropical forest (Hymenoptera: Apidae)," Journal of the Kansas Entomological Society, vol. 55, pp. 789-800, 1982.

[11] F. B. Noll, "Foraging behavior on carcasses in the necrophagic bee Trigona hypogea (Hymenoptera: Apidae)," Journal of Insect Behavior, vol. 10, no. 3, pp. 463-467, 1997.

[12] H. F. Schwarz, "Stingless bees (Meliponidae) of the Western Hemisphere," Bulletin of the American Museum of Natural History, vol. 90, pp. 1-546, 1948.

[13] D. W. Roubik, "Obligate necrophagy in a social bee," Science, vol. 217, no. 4564, pp. 1059-1060, 1982.

[14] J. M. F. Camargo and D. W. Roubik, "Systematics and bionomics of the apoid obligate necrophages: the Trigona hypogea group (Hymenoptera: Apidae; Meliponinae)," Biological Journal of the Linnean Society, vol. 44, no. 1, pp. 13-39, 1991.

[15] C. Rasmussen and J. M. F. Camargo, "A molecular phylogeny and the evolution of nest architecture and behavior in Trigona s.s. (Hymenoptera: Apidae: Meliponini)," Apidologie, vol. 39, no. 1, pp. 102-118, 2008.

[16] D. C. Somerville, "Nutritional value of bee collected pollen," Report for the Rural Industries Research and Development Corporation, Rural Industries Research and Development Corporation, Barton, Australia, 2001.

[17] G. J. Kleinschmidt and A. C. Kondos, "Influence of crude protein levels on colony production," The Australasian Beekeeper, vol. 78, pp. 36-39, 1976.

[18] E. J. Slaa, L. A. S. Chaves, K. S. Malagodi-Braga, and F. E. Hofstede, "Stingless bees in applied pollination: practice and perspectives," Apidologie, vol. 37, no. 2, pp. 293-315, 2006.

[19] M. Cortopassi-Laurino, V. L. Imperatriz-Fonseca, D. W. Roubik et al., "Global meliponiculture: challenges and opportunities," Apidologie, vol. 37, no. 2, pp. 275-292, 2006.

[20] F. G. Vossler, "Flower visits, nesting and nest defence behaviour of stingless bees (Apidae: Meliponini): suitability of the bee species for meliponiculture in the Argentinean Chaco region," Apidologie, vol. 43, no. 2, pp. 139-161, 2012.
[21] A. Roig-Alsina, F. G. Vossler, and G. P. Gennari, "Stingless bees in Argentina," in Pot Honey: A Legacy of Stingless Bees, P. Vit, S. R. M. Pedro, and D. W. Roubik, Eds., pp. 125-134, Springer, New York, NY, USA, 2013.

[22] P. Arenas, Etnografía y Alimentación Entre los TobaNachilamoleek y Wichí Lhuku'tas del Chaco Central (Argentina), Pastor Arenas Publisher, Buenos Aires, Argentina, 2003.

[23] A. L. Cabrera, "Fitogeografía de la República Argentina," Boletín de la Sociedad Argentina de Botánica, vol. 14, pp. 1-42, 1971.

[24] D. E. Prado, "What is the Gran Chaco vegetation in South America? I. A review. Contribution to the study of flora and vegetation of the Chaco," Candollea, vol. 48, pp. 145-172, 1993.

[25] G. Erdtman, "The acetolysis method, a revised description," Svensk Botanisk Tidskrift, vol. 54, pp. 561-564, 1960.

[26] F. O. Zuloaga, O. Morrone, and M. J. Belgrano, Catálogo de las Plantas Vasculares del Cono Sur (Argentina, Sur de Brasil, Chile, Paraguay y Uruguay), vol. 107, Monographs in Systematic Botany from the Missouri Botanical Garden, 2008.

[27] AOAC (Association of Official Analytical Chemists), Official Methods of Analysis, AOAC, Washington, DC, USA, 1980.

[28] J. M. Bremner and C. S. Mulvaney, "Nitrogen-total," in Methods of Soil Analysis. Part 2. Chemical and Microbiological Properties, A. L. Page, R. H. Miller, and D. R. Keeney, Eds., pp. 595-624, American Society of Agronomy, Madison, Wis, USA, 1982.

[29] T. H. Roulston and J. H. Cane, "Pollen nutritional content and digestibility for animals," Plant Systematics and Evolution, vol. 222, no. 1-4, pp. 187-209, 2000.

[30] E. W. Herbert, "Honey bee nutrition," in The Hive and the Honey Bee, J. E. Graham, Ed., pp. 197-233, Dadant \& Sons, Hamilton, Ill, USA, 1992.

[31] J. Adámoli, E. Sennhauser, J. M. Acero, and A. Rescia, "Stress and disturbance: vegetation dynamics in the dry Chaco region of Argentina," Journal of Biogeography, vol. 17, no. 4-5, pp. 491500, 1990.

[32] S. D. Leonhardt and M. Kaltenpoth, "Microbial communities of three sympatric Australian stingless bee species," PLoS ONE, vol. 9, no. 8, Article ID e105718, 2014.

[33] È. Butler, M. Alsterfjord, T. C. Olofsson, C. Karlsson, J. Malmström, and A. Vásquez, "Proteins of novel lactic acid bacteria from Apis mellifera mellifera: an insight into the production of known extra-cellular proteins during microbial stress," $B M C$ Microbiology, vol. 13, article 235, 2013.

[34] J. H. Cane and S. Sipes, "Characterizing floral specialization by bees: analytical methods and a revised lexicon for oligolecty," in Plant-Pollinator Interactions from Specialization to Generalization, N. M. Waser and J. Ollerton, Eds., pp. 99-122, University of Chicago Press, Chicago, Ill, USA, 2006.

[35] A. C. Andrada and M. C. Tellería, "Pollen collected by honey bees (Apis mellifera L.) from south of Caldén district (Argentina): botanical origin and protein content," Grana, vol. 44, no. 2, pp. 115-122, 2005.

[36] A. Forcone, P. V. Aloisi, S. Ruppel, and M. Muñoz, "Botanical composition and protein content of pollen collected by Apis mellifera L. in the north-west of Santa Cruz (Argentinean Patagonia)," Grana, vol. 50, no. 1, pp. 30-39, 2011.

[37] F. E. Todd and O. Bretherick, "The composition of pollens," Journal of Economic Entomology, vol. 35, no. 3, pp. 312-317, 1942.

[38] W. F. McCaughey, M. Gilliam, and L. N. Standifer, "Amino acids and protein adequacy for honey bees of pollens from desert plants and other floral sources," Apidologie, vol. 11, no. 1, pp. 75$86,1980$. 
[39] F. G. Vossler, M. C. Tellería, and M. Cunningham, "Floral resources foraged by Geotrigona argentina (Apidae, Meliponini) in the Argentine Dry Chaco forest," Grana, vol. 49, no. 2, pp. 142-153, 2010.

[40] T. H. Roulston, J. H. Cane, and S. L. Buchmann, "What governs protein content of pollen: pollinator preferences, pollen-pistil interactions, or phylogeny?" Ecological Monographs, vol. 70, no. 4, pp. 617-643, 2000.

[41] A. Basilio and M. Noetinger, "Análisis polínico de mieles de la Región Chaqueña: comparación del origen floral entre las zonas Domo Central y Esteros, Cañadas y Selvas de Rivera," Revista de Investigaciones Agropecuarias, vol. 31, no. 2, pp. 127-134, 2000.

[42] M. Cabrera, "Caracterización polínica de las mieles de la provincia de Formosa, Argentina," Revista del Museo Argentino de Ciencias Naurales Bernardino Rivadavia N.S., vol. 8, pp. 135142, 2006.

[43] C. R. Salgado, Flora melífera en la provincia del Chaco, Edited by PROSAP, Impreso por Ministerio de la Producción del Chaco, 2006.

[44] A. M. Basilio, C. Spagarino, L. Landi, and B. Achával, "Miel de Scaptotrigona jujuyensis en dos localidades de Formosa, Argentina," in Stingless Bees Process Honey and Pollen in Cerumen Pots, P. Vit and D. W. Roubik, Eds., pp. 1-8, Facultad de Farmacia y Bioanálisis, Universidad de Los Andes, Mérida, Venezuela, 2013, http:/www.saber.ula.ve/handle/123456789/ 3529.

[45] F. G. Vossler, G. A. Fagúndez, and D. C. Blettler, "Variability of food stores of Tetragonisca fiebrigi (Schwarz) (Hymenoptera: Apidae: Meliponini) from the Argentine Chaco based on pollen analysis," Sociobiology, vol. 61, no. 4, pp. 449-460, 2014.

[46] A. C. Andrada and M. C. Tellería, "Botanical origin of honey from south of Caldén district (Argentina)," Grana, vol. 41, no. 1, pp. 58-62, 2002.

[47] A. Forcone, G. Ayestarán, A. Kutschker, and J. García, "Palynological characterization of honeys from the Andean Patagonia (Chubut, Argentina)," Grana, vol. 44, no. 3, pp. 202-208, 2005. 

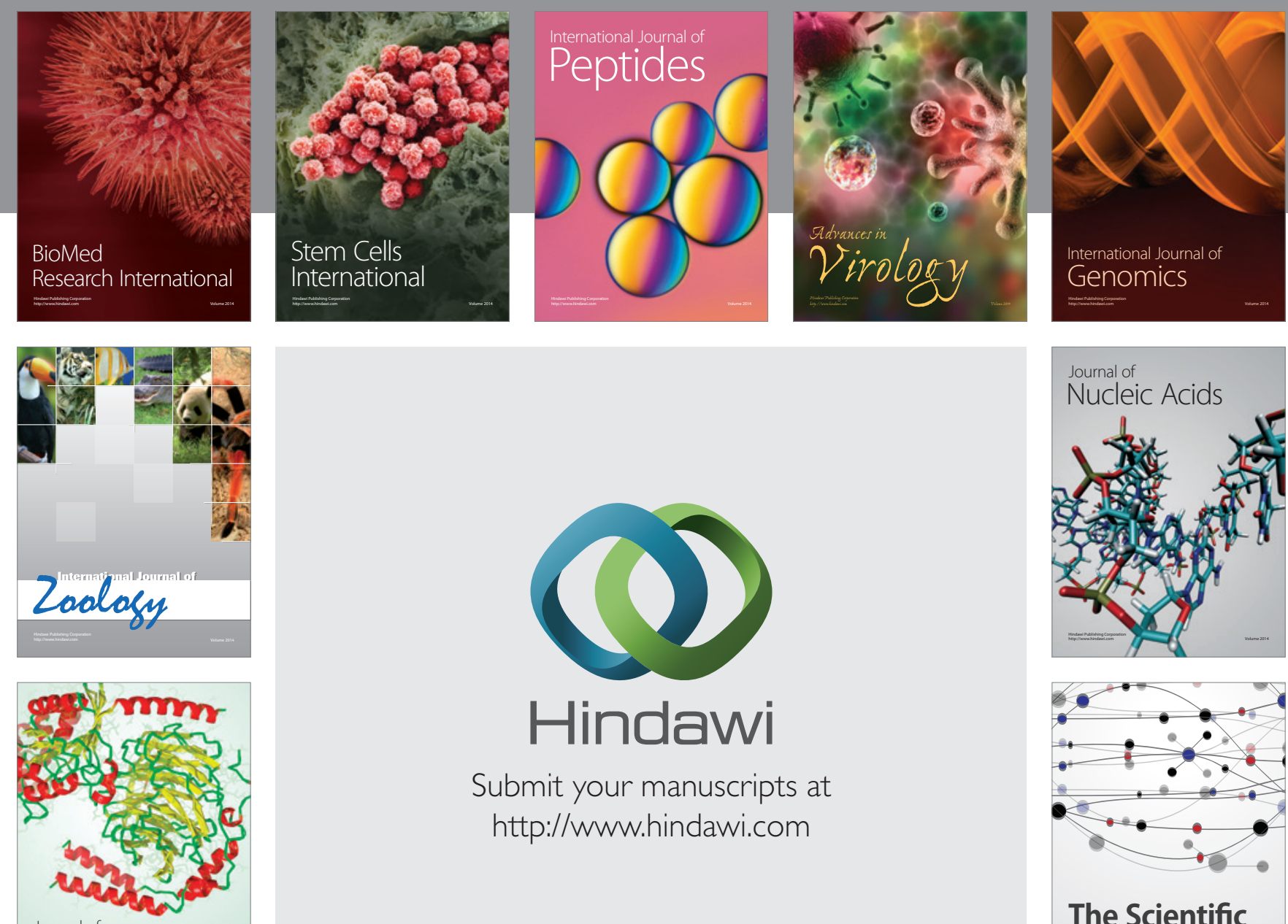

Submit your manuscripts at

http://www.hindawi.com

Journal of
Signal Transduction
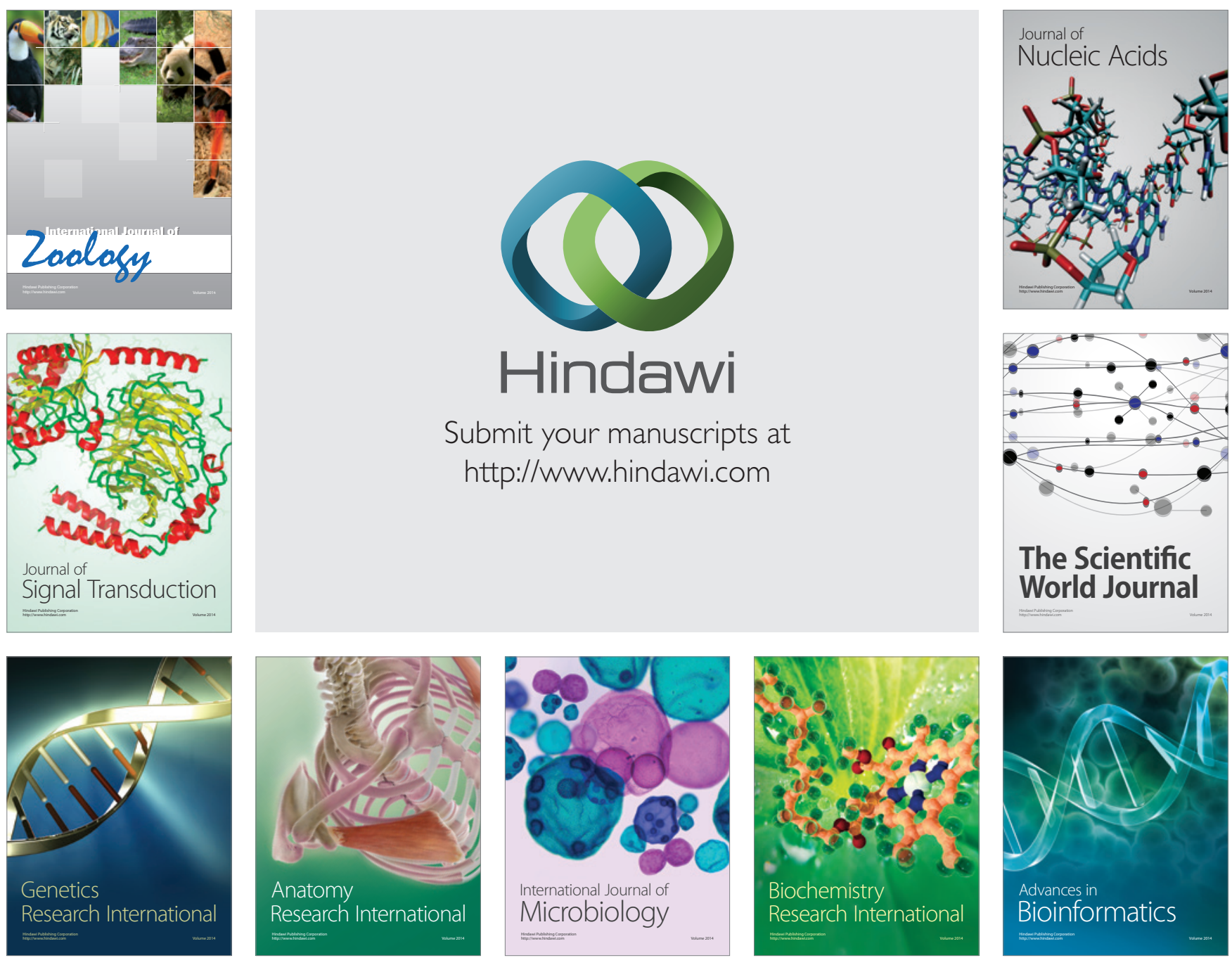

The Scientific World Journal
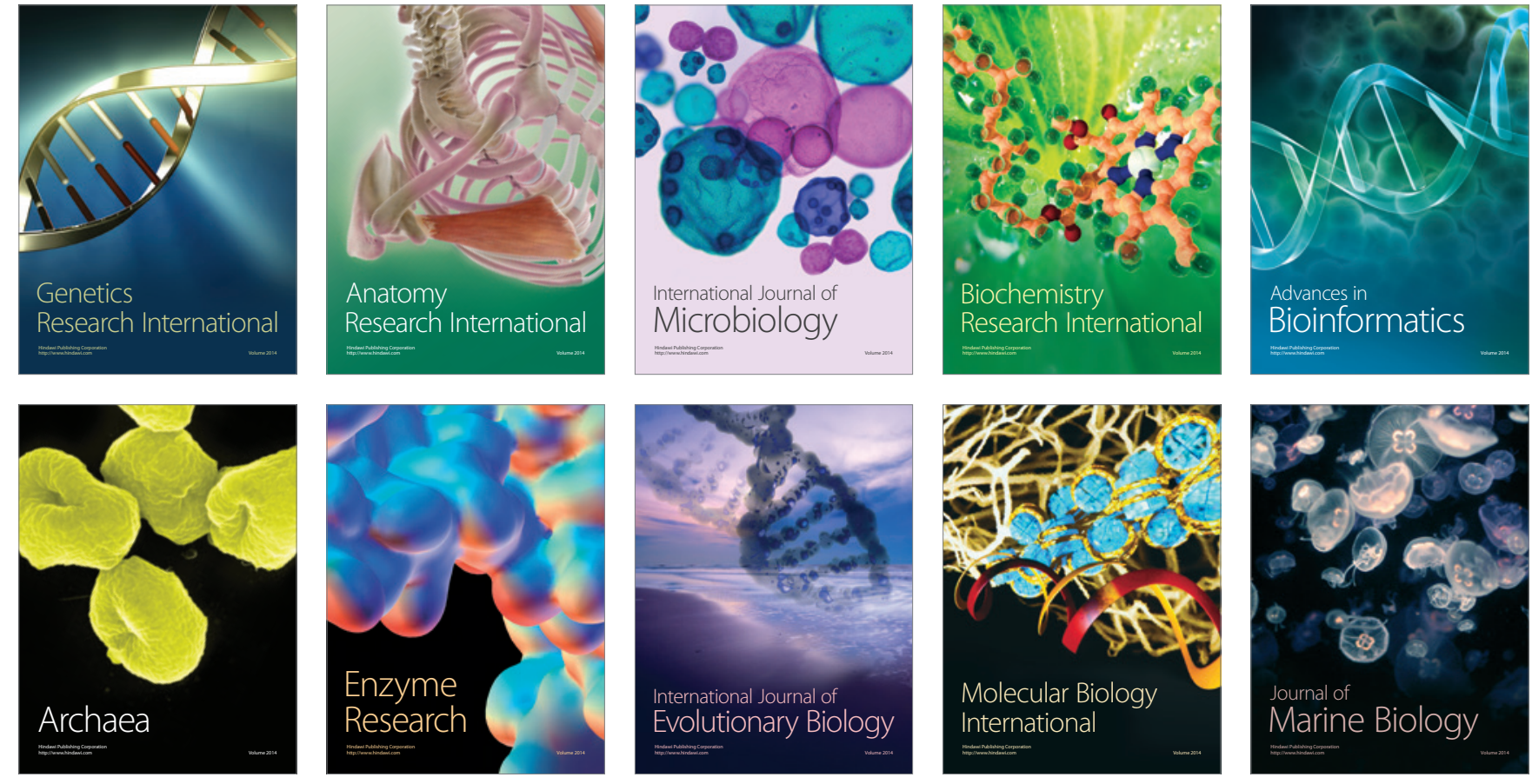